\title{
Photointerpretation of Tertiary structures in platform cover strata of interior Oscar II Land, Spitsbergen
}

\author{
HARMON D. MAHER, JR.
}

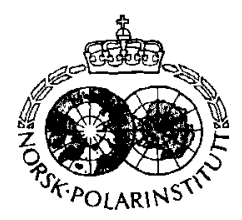

\begin{abstract}
Maher, H. D., Jr. 1988: Photointerpretation of Tertiary structures in platform cover strata of interior Oscar II Land, Spitsbergen. Polar Research 6, 155-172.

A structural map of Oscar II Land compiled using black and white, stereo-pair air photos and other available information sources suggests the existence of three structural zones within the deformed platform cover strata. The western zone consists of basement involved overthrusts of complex geometry in the north and large-scale folds of platform cover strata with a stepped, down to the east profile in the south. The central zone consists primarily of folds within Kapp Starostin Fm. and overlying Triassic strata that likely formed above a subhorizontal decollement within Gipshuken Fm. strata. Farther to the east thrusts emplace Permian Kapp Starostin Fm. strata over Triassic strata. This zone probably represents stratigraphic climb of the basal décollement. Conservative estimates of shortening for the central and eastern zones are in the 15-25\% range. The contribution of the western zone structures to overall Tertiary shortening depends on the geometry of faults underlying the stepped folds and is uncertain at present.

Changes along strike are in part due to differential levels of erosion and changes in transport direction, but also probably important was variable thickness of the platform cover strata involved (less to the north) and the availability of incompetent horizons along which thrust-flats could form. Two areas with anomalous structural trends may represent oblique ramps.
\end{abstract}

H. D. Maher, Norsk Polarinstitutt, P.O. Box 158, N-1330 Oslo Lufthavn, Norway and Dept. of Geography and Geology, University of Nebraska-Omaha, Omaha, NE 68182, U.S.A. (perm. residence). March 1988 (revised September 1988).

Tertiary age folds and thrusts on Spitsbergen affect both Hecla Hoek basement rocks (deformed and metamorphosed in Caledonian and older events) and the overlying Upper Paleozoic and Mesozoic platform cover strata. These structures, which define a belt subparallel to the present continental margin, formed during the initial opening of the Norwegian-Greenland and Arctic oceanic basins, were intracontinental, and were temporally associated with major dextral transcurrence linking spreading in the two oceanic basins (Harland 1969; Lowell 1972; Myhre et al. 1982; Eldholm et al. 1987). Such a setting contrasts with the typical convergence-related, continental margin setting of most fold-and-thrust belts. They are of interest because of their unusual setting and are the subject of renewed investigation (e.g. Andresen et al. 1968; Haremo \& Andresen 1988; Nøttvedt \& Rasmussen 1988; Dallmann 1988). A basic question that arises given this unusual tectonic setting is with regard to the large scale crustal architecture. Lowell (1972) proposed a model of flower structures where sub-vertical transcurrent faults at depth had a dip slip component and bent into low-angle en echelon thrusts at shallower crustal levels. Since Lowell's 1972 paper was one of the earlier formulations of the flower model, Spitsbergen in some respects has become a 'type' example.

An alternative model of decoupled transcurrent and convergent components extant in two parallel belts can be argued for (Maher \& Craddock 1983, 1988; Haremo \& Andresen 1988), but is not a focus of this paper. However, in order to test rigorously and constrain these and other models, a map of Spitsbergen's Tertiary structures is being compiled at Norsk Polarinstitutt as a basic information base. Detailed maps with structural information have been published for some areas (e.g. Orvin 1934; Challinor 1967; Birkenmajer 1964, 1977; Maher et al. 1986; Andresen et al. 1988b; Dallman 1988; a partial list), but several large gaps exist.

One of these gaps is in interior Oscar II Land, where glacial ice makes access difficult. Air photos along with other sources of information were used to produce a structural map of the Tertiary structures within the platform cover 
sequence of this area, specifically of parts of the Tre Kroner and St. Jonsfjorden 1:100,000 topographic map sheets (Fig. 2). Structures were located on the topographic compilation base by inspection and comparison with the topography evident on the air photos. With many distinctive ridges and glaciers this presented little difficulty. It is important to emphasize that this is not a conventional geologic map. It is more interpretive, and has several inherent biases (discussed below). Detailed mapping will be necessary to correct and/or confirm the map interpretation (ground-truth).

Also, Arild Andresen (pers. comm.) and Steffen Bergh (University of Oslo and University of Troms $\emptyset$, respectively) are mapping with students along the north shore of Isfjorden (Bergh et al. $1988 \mathrm{a}, \mathrm{b})$ and the reader should be aware that detailed results should be forthcoming for part of the area included in the present report. The focus of this report is presentation of the results of the photointerpretation, an analysis of three structural zones that can be recognized from this compilation, and some suggestions for further research.

\section{Compilation sources}

Holtedahl (1913) describes local aspects of the stratigraphy and structure of this area and includes panoramic plates of various mountain sides. Flood et al. (1971) and Hjelle \& Lauritzen (1982) provide large scale $(1: 500,000)$ maps that include the study area and suggest the general range of stratigraphic units exposed in a given area. Unpublished notes, maps of, and personal communication with Ohta, Winsnes, and Keilen at Norsk Polarinstitutt have been invaluable in the compilation of the map.

The primary air photo set used is the black and white, vertical, overlapping (providing stereocoverage) S70 series, numbers 4506-5963, residing at Norsk Polarinstitutt. The scale is approximately $1: 17,000$ and quite a bit of structural detail is discernible. While the S70 series cover most of Oscar II Land, an area just $\mathrm{N}$ of Borebukta is not covered, and the S66 series at a scale of approximately $1: 50,000$ were used with less satisfactory results. Various oblique airphotos in the Norsk Polarinstitutt collection helped in the interpretation of vertical stereopairs.

\begin{tabular}{|c|c|c|c|c|}
\hline A & Helvetiaf jellet $\mathrm{Fm}$. & Creteceous & $\begin{array}{l}\text { terrestrial sandstone, } \\
\text { siltstones \& some coals }\end{array}$ & $100 \mathrm{~m}$ \\
\hline $\mathbf{B}$ & Janusf jellet Subgroup & $\begin{array}{l}\text { Crotaceous \& } \\
\text { Jurassic }\end{array}$ & $\begin{array}{l}\text { organic rich, black, } \\
\text { marino ghales }\end{array}$ & $\begin{array}{l}400- \\
600 \mathrm{~m}\end{array}$ \\
\hline C & Kapp Toscena Group & Triese1c & $\begin{array}{l}\text { mainly terrestrial } \\
\text { clestics }(39-s h)\end{array}$ & $250 \mathrm{~m}$ \\
\hline c & Saseendelen Troup & Triassic & $\begin{array}{l}\operatorname{marine} \text { deltaic clastics } \\
(99-8 h)\end{array}$ & $825 \mathrm{~m}$ \\
\hline D. & Kapp Starostin Fm. & Permian & $\begin{array}{l}\text { fossiliferous limestone } \\
\text { \& dark spiculitic chert }\end{array}$ & $\begin{array}{l}380- \\
460 \mathrm{~m}\end{array}$ \\
\hline E & Gipshuken $\mathrm{Fm}$. & Permian & dolomitas \& gypsums & $160 \mathrm{~m}$ \\
\hline$\varepsilon$ & Nordenskläldbreen $\mathrm{Fm}$. & $\begin{array}{l}\text { Permian \&/or } \\
\text { Carboniferaus }\end{array}$ & $\begin{array}{l}\text { ehallow marine } \\
\text { dolomites }\end{array}$ & $\begin{array}{l}115- \\
260 \mathrm{~m}\end{array}$ \\
\hline $\mathbf{F}$ & $\begin{array}{l}\text { Petrelskardet } \\
\text { Tarkanten } F m 8 .\end{array}$ & Carbontferous & $\begin{array}{l}\text { arid, shallow marine } \\
\text { dolomitos \& sandstones }\end{array}$ & $? ?$ \\
\hline $\boldsymbol{F}$ & Oillefjorden Group & Cerbondferous & $\begin{array}{l}\text { fluvial and floodplain } \\
\text { clastics }\end{array}$ & $? ?$ \\
\hline & Wood Bay $\mathrm{Fm}$. & Devonian & $\begin{array}{l}\text { veriety of red colored } \\
\text { clastlcs }\end{array}$ & $? ?$ \\
\hline
\end{tabular}

Fig. 1. Formal lithostratigraphic units (Hjelle \& Lauritzen 1982) within the study area. Letters A-H refer to units on photointerpretation map (Fig. 2). Revised stratigraphic nomenclature can be found in Steel \& Worsley (1984) 


\section{Recognition of map units on air photos}

Eight units (Fig. 1) and seven boundaries were mapped on the basis of air photo grey tones, comparative slope angles and textures (roughness or extent of small scale topography), the definition of bedding, and other traits described below.

Hecla Hoek basement has a quite variable air photo appearance, and no single set of distinguishing criteria can be used with the exception, perhaps, that they are characterized by somewhat more rugged topography with common multiple topographic lineaments typical of metamorphic rocks. As a fundamental boundary the position of the basement-platform cover contact has been fairly well established by previous work (e.g. Flood et al. 1971; Hjelle \& Lauritzen 1982).

Devonian clastics exhibit smooth, fairly dark, moderate to low angle slopes on the air photos. Abundant talus often obscures bedding. In the northeastern part of the study area the upper boundary of the Devonian is marked by a sharp slope break against the more resistant overlying Carboniferous to Permian Nordenskiöldbreen Fm.

Carboniferous Billefjorden Group quartzites have been included with the Petrelskardet and Tarrnkanten $\mathrm{Fm}$. clastics and carbonates as one unit. The quartzites have fairly light grey tones, are resistant, but often have a smooth appearance, while the overlying clastics (often with a red-orange tint in the field, Gjelberg \& Steel 1981) are medium grey and associated with moderate and relatively smooth slopes. Bedding is typically obscured or difficult to detect in the air photos.

Nordenskiöldbreen and Gipshuken Fms. consist primarily of light-grey dolomites, occasional clastics, and, locally within the Gipshuken Fm., well developed gypsum horizons. Nearly identical in appearance, the two formations are mapped here as one urit. On air photos they are characterized by light to medium grey tones, moderate slope angles, rough slope textures, and fairly distinct bedding.

Conspicuous on the air photos, Kapp Starostin Fm. (Fig. 1) dark spiculitic cherts and light colored fossiliferous limestones provide an important marker horizon. The color contrast between the two dominant lithologies distinctly defines bedding in many air photos. High slope angles and variable slope textures typify this unit. Dip slopes within the limestones are common.

Triassic clastics (Fig. 1) provide a marked contrast with the underlying Permian Kapp Starostin Fm. Bedding within the Triassic strata is typically discernible as color bands, ridges of alternating resistance, and dip slopes, but locally is not apparent, probably because of extensive talus cover. Slope angles are moderate and slope texture is smooth. In some areas one can pick out and trace the Botneheia Fm. (upper Sassendalen Group, Hjelle \& Lauritzen 1982) on air photos for a map distance of several $\mathrm{km}$ as a darker band (due to the high proportion of organic-rich, dark shales) of appropriate thickness between lighter colored clastics of the underlying Sticky Keep Fm. and overlying Kapp Toscana Group. If the lighter colored, more resistant Kapp Toscana Group strata are not exposed, the base of the Botneheia Fm. may have been mistaken as the base of the Janusfjellet Subgroup, which is also composed of dark organic-rich shales.

The homogeneity, tendency to slump, and generally poor surface exposures of the Janusfjellet Subgroup black shales do not permit much structural interpretation from the air photos. Cretaceous age Helvetiafjellet Fm. clastics are the highest stratigraphic units exposed in the study area. Their much lighter color, higher slopes, and rugged topography are in marked contrast to the underlying Janusfjellet shales.

\section{Results of photointerpretation}

Fig. 2 presents the structural map compiled from the above sources. Original compilation was on a topographic map base of $1: 100,000$. The scale of Fig. 2 has necessitated deletion of some details. Certain structural biases are inherent in this map. Folds are easier to detect than faults, especially thrusts with a shallow dip. Where a reversal in dip occurs without an exposed intervening hinge zone, either a fold has been inferred (an ' $i$ ' on the map signifies an inferred structure) if the strata in the two 'limbs' look similar, or a fault if they are dissimilar. A composite fold-fault symbol signifies uncertain cases. Faults with a high-angle stratal discordance are easier to detect than those with a low-angle discordance. Imbricated sequences, especially within the Triassic strata, may appear as homoclinal ones since the detailed local stratigraphy is not discernible from air photos alone. 


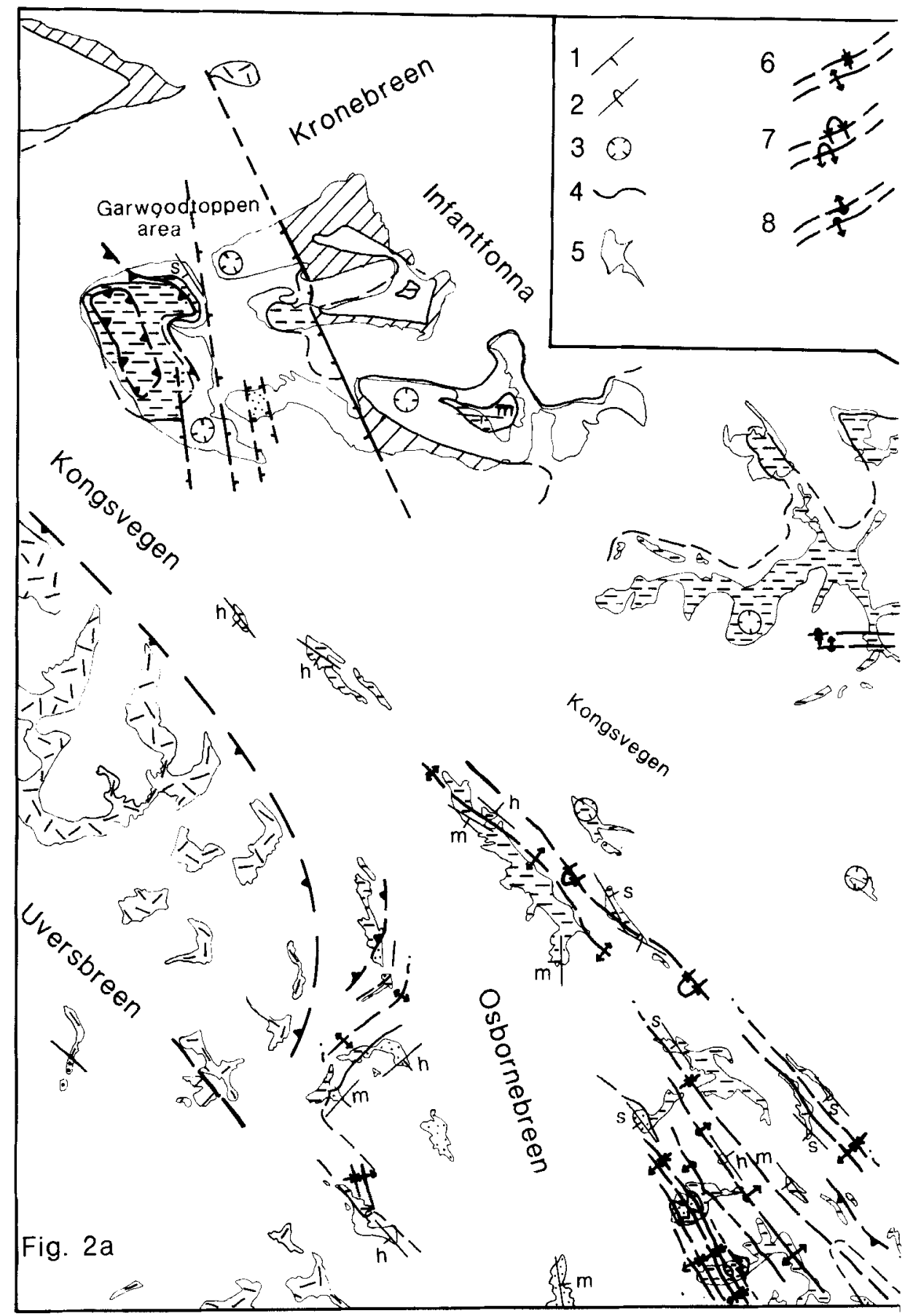

Fig. 2. Compilation map of Tertiary structures of interior Oscar II Land based on air photointerpretation and other information sources. a) Part of Tre Kroner topographic sheet. b) Part of St. Jonsfjorden topographic sheet. Structural symbols as follows: 1 approximate strike and dip of bedding estimated from air photos; $s$ - shallow dip (<20 degrees), $m$ - moderate dip (20-60 degrees), 


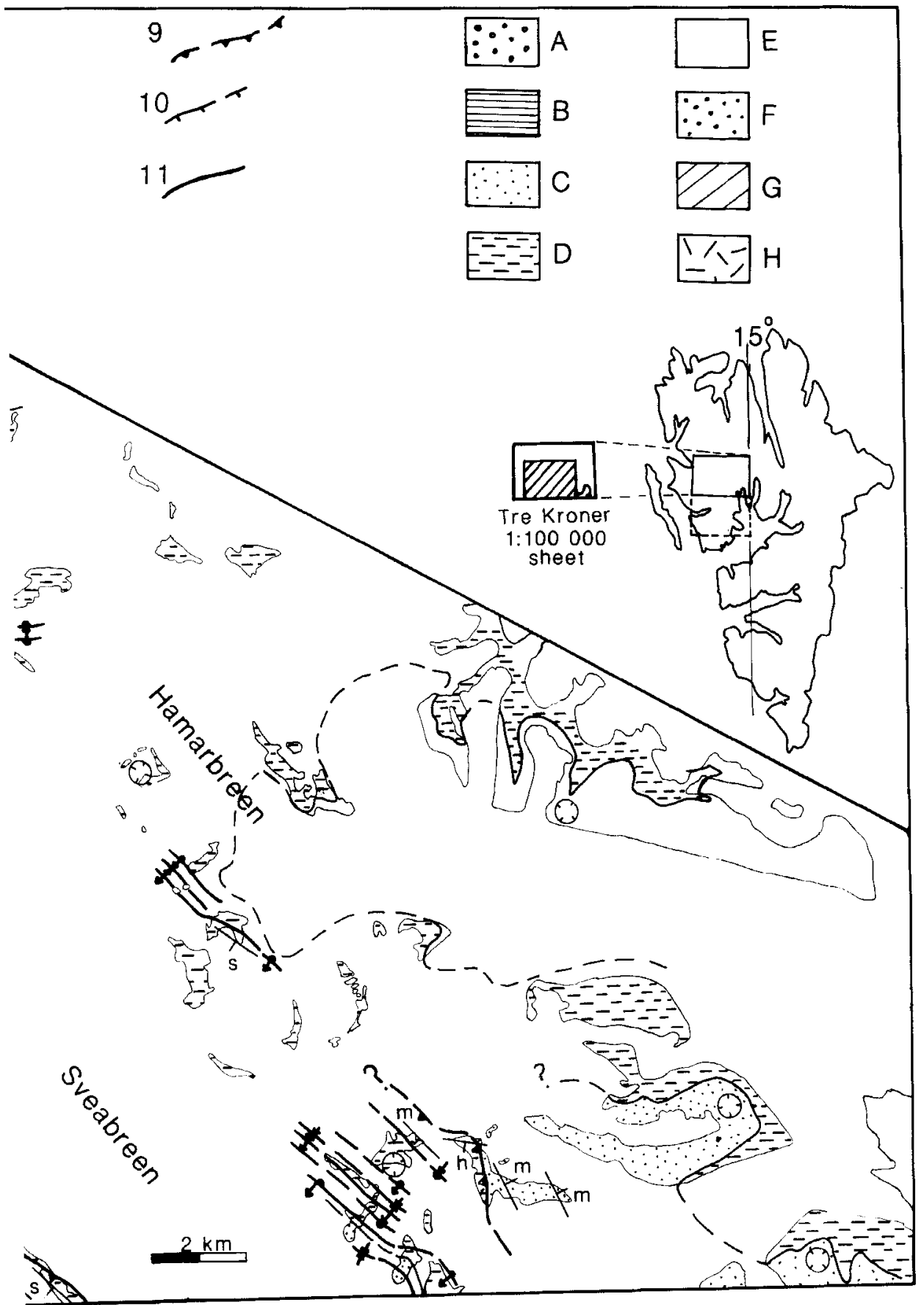

h-steep dip. 2 - same as above, but overturned bedding. 3 - subhorizontal bedding. 4 - geologic boundary. 5 -outline of nunataks and rock exposure. 6 - synclinal and anticlinal axial traces. 7 - overturned synclinal and anticlinal axial traces. 8 - monoclinal axial traces. 9 - thrust fault. 10 - normal fault. 11 - fault of unknown slip. All lines dashed where inferred. Map units (A-H) described in Fig. 1. 


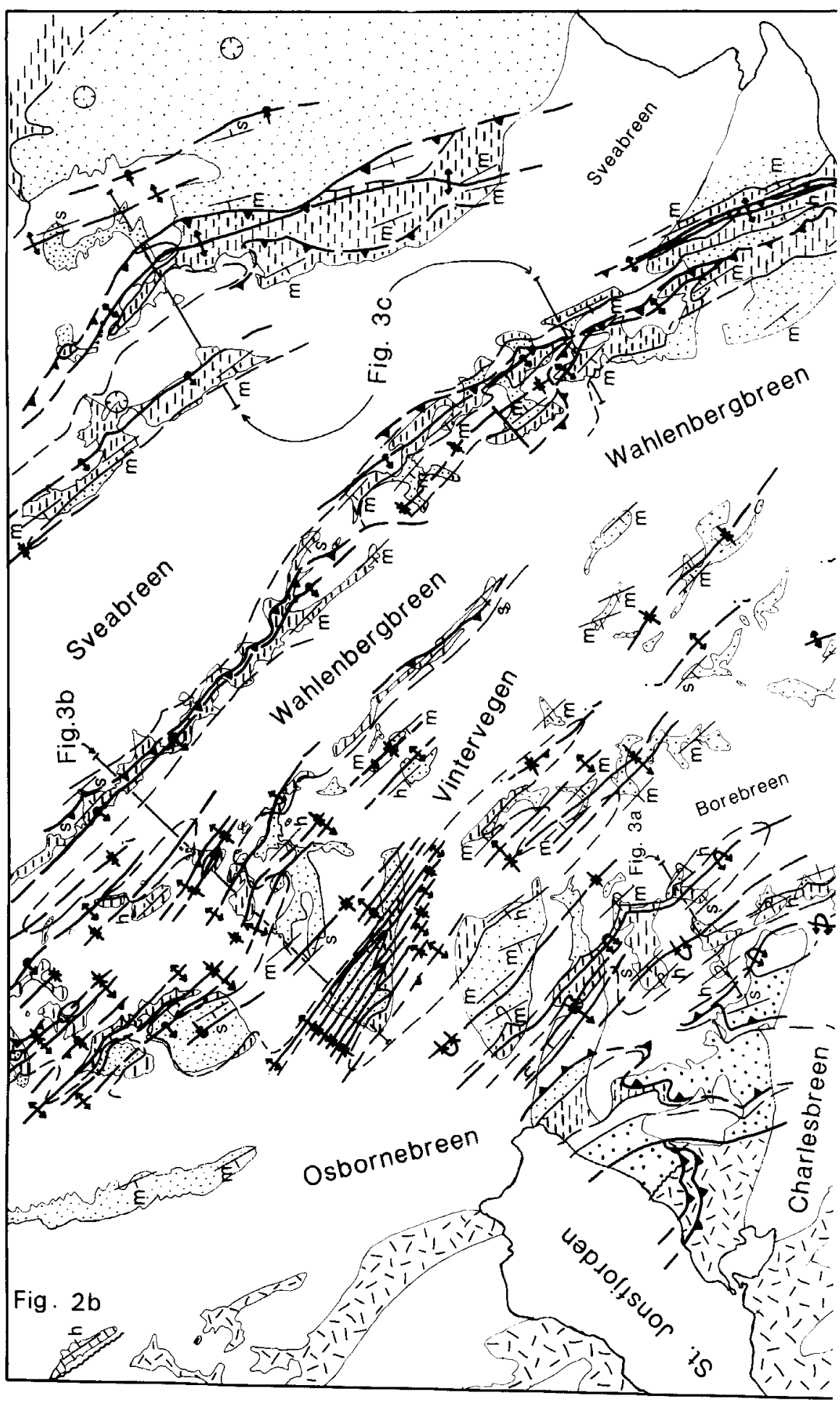

Fig. 2. continued. 


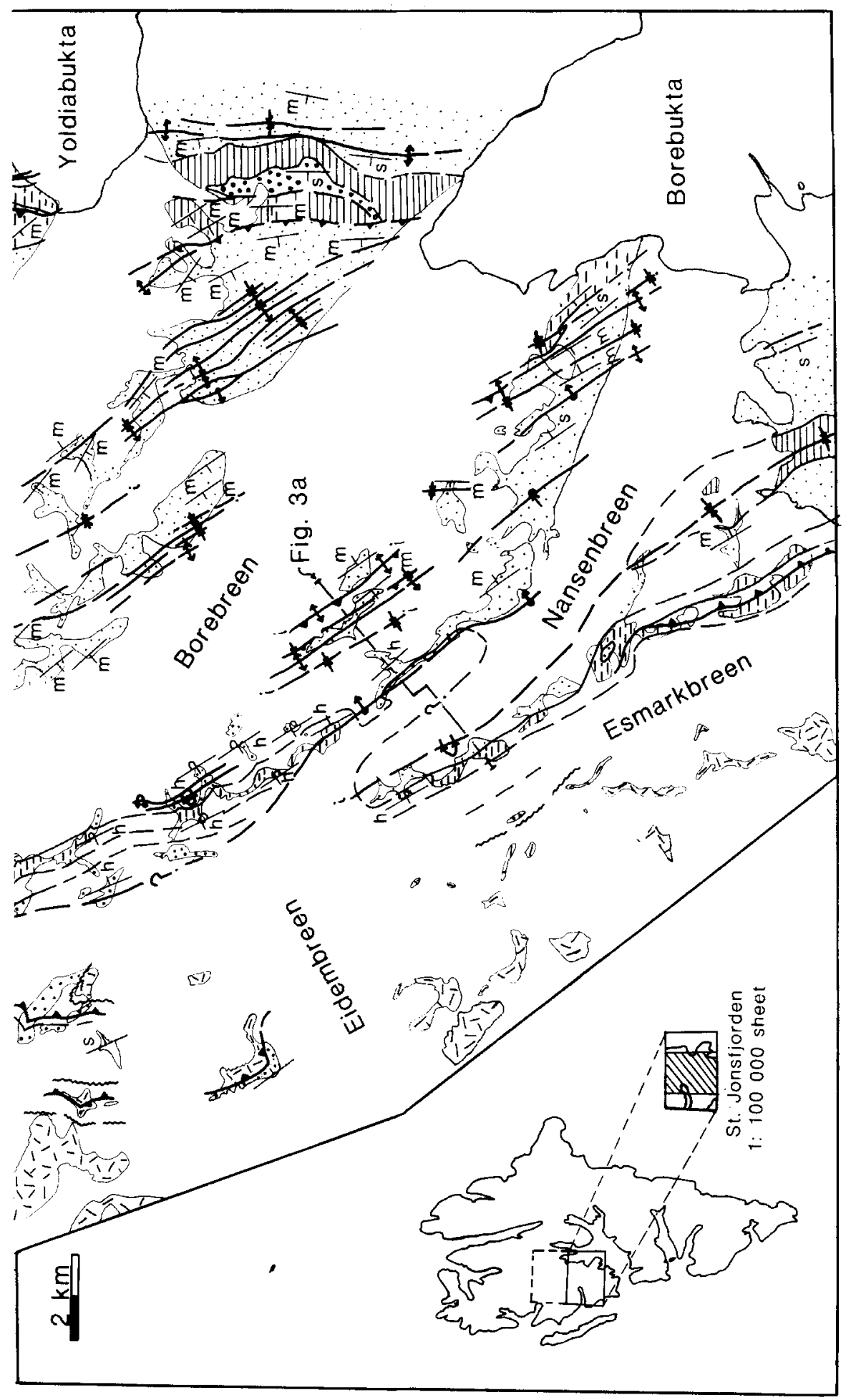



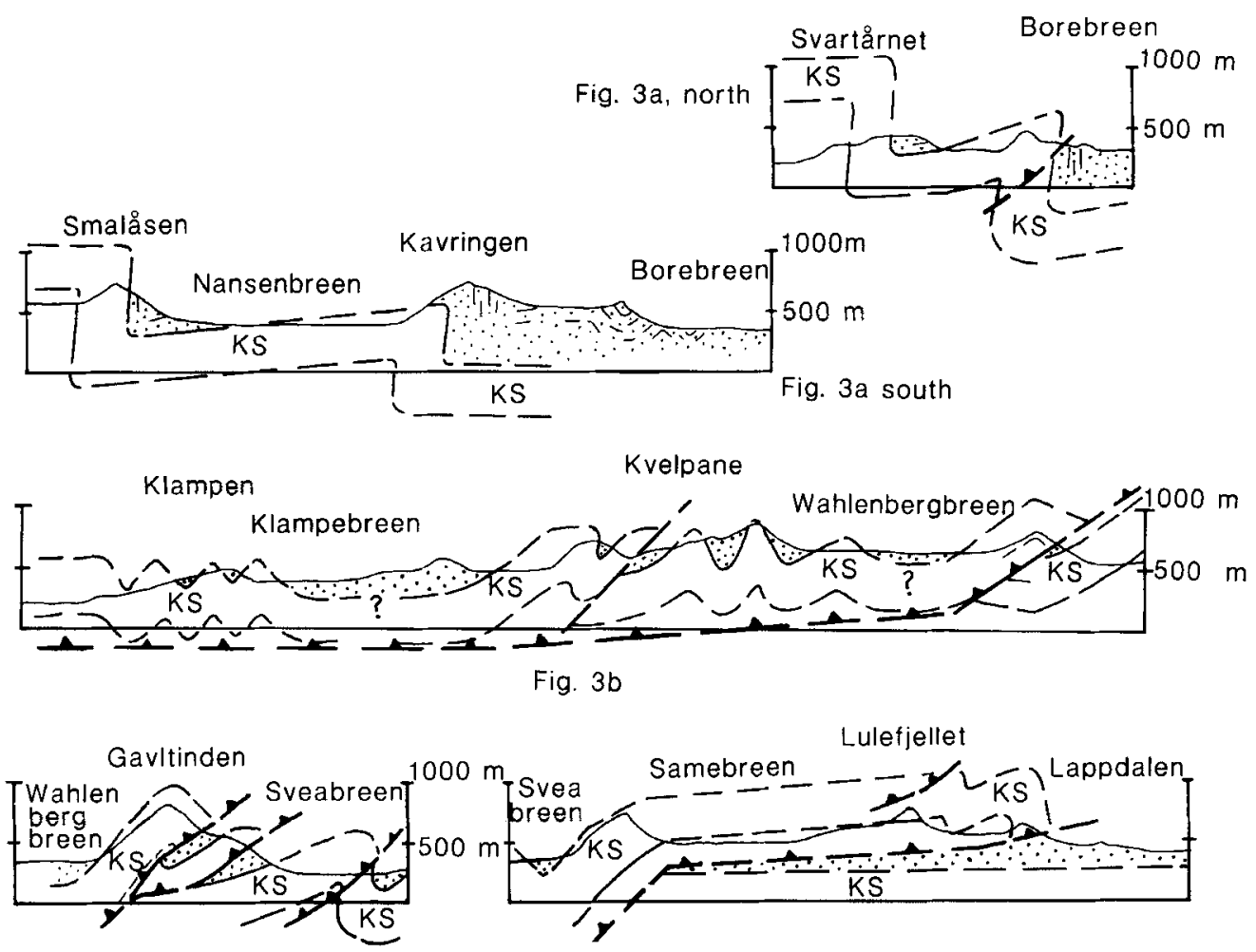

Fig. 3c, south

Fig. $3 c$ north

Fig. 3. W to E cross sections from Fig. 2. See text for discussion. KS - Kapp Starostin Fm. Vertical and horizontal scales equal.

Question marks indicate structures that have a notably more speculative basis.

The resulting map pattern suggests that three zones with distinctive structural styles exist. From west to east these are:

1) A zone characterized in the north by thrusts with a complex geometry emplacing Hecla Hoek rocks into and over the lower platform cover strata (from the Brøggerhalvøya area to St. Jonsfjorden), and characterized in the south by a series of stacked monoclinal to overturned folds of Kapp Starostin Fm. strata that form a 'staircase' type pattern in profile (Fig. 3a) descending to the east (found from the east end of St. Jonsfjorden down to Isfjorden). These folds are readily traceable on the air photos.

2) A central zone characterized by folds within upper Kapp Starostin Fm. and Triassic strata and without readily apparent major thrusts (movement greater than $1 \mathrm{~km}$ ).

3) A zone with at least two major thrusts that have emplaced Kapp Starostin Fm. strata over Triassic strata. Some of the folds, with more angular hinges and flat tops, are of a probable fault-bend fold style (Suppe 1985). Several smaller thrusts are also evident.

Each of these zones are described below in more detail in the order presented above.

\section{Western zone of basement overthrusts and 'staircase' folds}

Structural complexity where Hecla Hoek basement rocks are overthrust into the platform cover strata has been well documented in the Broggerhalvøya area (Challinor 1967) and exists at the east end of St. Jonsfjorden (Ohta pers. comm.). The complexity, which includes folded thrust surfaces, is of such a degree that air photo interpretation can add little new data. Detailed field 
mapping is necessary. However, given an overall southerly plunge of structures throughout the study area, these structures are significant to the present discussion in that they may represent a deeper (more northerly) structural level underlying the 'staircase' folds in Kapp Starostin Fm. strata that extend south of St. Jonsfjorden.

Fig. 3a shows a cross section profile of the staircase folds with a northeast vergence. Subhorizontal or shallowly west-dipping long limbs bend at subangular hinges into subvertical to overturned short limbs. In any one cross section at least two full steps occur, but if one extrapolates, four steps exist altogether along a $30 \mathrm{~km}$ strike length. The southernmost step is not included in the study area. Whether a true en echelon character exists, where some of these folds diminish and disappear along their axis, or whether the map pattern is controlled by the southerly structural plunge, is uncertain. There is considerable overlap between fold axial traces. The map widths of the shallowly west-dipping limbs decrease consistently from a map width of about $4 \mathrm{~km}$ in the west to $800-900 \mathrm{~m}$ in the east. Overlying Triassic strata are also involved in this folding. A similar pattern also exists in Nordenskiöld Land to the south across Isfjorden and this structural style may represent a fundamental aspect of Tertiary deformation in the platform cover strata of west Spitsbergen.

The structural position suggests these may be large fault-propagation or fault-bend folds. A single fold with eastern vergence could be explained as a monoclinal bend caused by rotation of a hangingwall cutoff that was transported onto a thrust flat. If another flat existed along the same thrust surface farther west at a deeper stratigraphic level, then such a fold would represent the leading edge of a ramp antiform. However, the staircase pattern and overturned limbs suggest a more complicated geometry of underlying faults.

For discussion's sake three different possible models are provided in Fig. 4. The first model
(Fig. 4a) explains the folds as fault-propagation folds where thrusts that emerge from the Hecla Hoek basement produce folds in the overlying competent Kapp Starostin Fm. strata. The faultto-fold transition would be accommodated within the relatively incompetent Gipshuken gypsums and dolomites. The steep overturned limbs favor this model.

The second model (Fig. 4b) explains these folds as associated with several independent ramp antiforms produced as slip is transferred upsection from within the Gipshuken Fm. to within basal Triassic strata by a ramp that cut through the Kapp Starostin Fm. An important prediction of this model is that the continuity of synclinal hinges of the staircase pattern would only be apparent and instead a hangingwall cutoff of Kapp Starostin Fm. strata lies above a footwall flat at the top of the formation. However, Triassic strata above the level of a basal slip plane (flat) would be continuous across the synclinal hinge. The Berzeliustinden thrust to the south in the Bellsund area shows a thrust truncation of a steep, locally overturned limb of Kapp Starostin strata (Dallmann 1988). However, once again the overturned character of the limb indicates folding preceded faulting of the Kapp Starostin (in order to produce the implied cutoff angle and so an element of the first model is required). These structures would then be somewhat similar, although smaller in scale, to monoclinal flexures and asymmetric anticlines flanking the Rocky Mountain uplifts of Wyoming and Colorado in the U.S.A. (Berg 1962).

The third interpretation (Fig. 4c) explains the staircase pattern as a result of ramps that emerged from the Hecla Hoek up to the Gipshuken gypsums where they bent into a flat. All slip would have been transferred along this horizon farther east beyond this zone. An age progression of successively younger ramps and leading edges to the east (breakforward sequence) is required by this model. One interesting implication of this model which is absent in the other two models is a.

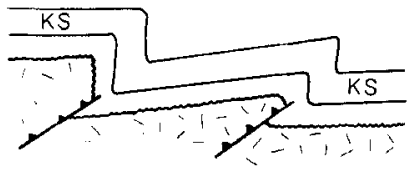

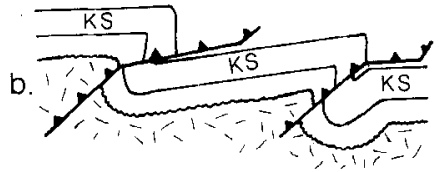

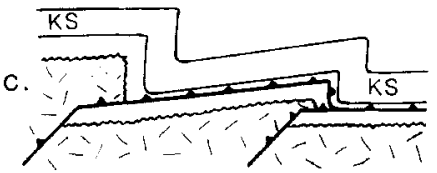

Fig. 4. Three different interpretations of underlying fault geometry for the 'staircase' folds in Kapp Starostin Fm. of the western zone. 
the folding of thrust surfaces, which is observed to the north as previously mentioned. However, overturned limbs would not be expected.

As can be seen from the above discussion, each model is inadequate by itself. However, a combination of the first and third model would explain the overturned limbs and east-dipping (folded) thrust planes, respectively. Also, the first two models have a different implication for the overall shortening within the Tertiary fold-andthrust belt than does the third model. In the first two models movement is on independent thrust surfaces and slip would be transferred to higher levels, presumably no longer preserved by the present erosion level. In other words, any shortening evident in the surface structures of this zone would be in addition to that found farther east. In contrast, the third model implies that slip is transferred farther east, in which case the structures preserved to the east represent the accommodation of this same slip. One focus of future research on Tertiary structures in Svalbard could be the determination of the fault geometry underlying these folds.

Some suggestion as to the minimum amount of shortening that is represented in this zone can be quickly gauged from the minimum height of the subvertical limbs. For the two such steps in Fig. 3a a minimum of $1.3 \mathrm{~km}$ shortening exists. If four steps actually do exist along the entire strike length then one can infer some 2.4 or greater $\mathrm{km}$ of shortening.

\section{Central zone of folding}

Fig. 3b displays structures typical of this zone. Open to tight folds of Kapp Starostin Fm. and Triassic strata have a variety of styles from conjugate (Fig. 5) to more rounded fold forms (Fig. 6). The ability of Kapp Starostin Fm. strata to form tight folds is a bit surprising given the much more competent manner they appear to behave south of Isfjorden (e.g. Maher et al. 1986) and to the west. The frequency of gypsum horizons in the underlying Gipshuken Fm. may in part determine the different structural responses in different areas. The folds do not appear to have any consistent asymmetry (vergence) and many of the axial planes are close to upright as far as can be ascertained from the air photos. Numerous small thrusts are likely within this zone but undetectable on air photos with a few exceptions (Fig. 5). Large thrusts $(>1 \mathrm{~km})$ have been ruled out in most areas since no major stratigraphic breaks were found.

One important observation is that in a W-E cross section the upper Kapp Starostin Fm. boundary is seen repeatedly at the surface (Fig. $3 b$ ). This suggests subhorizontal enveloping surfaces for the folds, which in turn suggest a major, subhorizontal underlying detachment. The Gipshuken Fm. gypsums represent one obvious candidate as suggested by Harland \& Horsfield (1974). With such an interpretation this zone represents thin-skinned deformation with folds forming above a 9-10 km wide 'mega-flat'. One important implication is that these would then represent 'buckle' folds above a relatively planar décollement instead of fault-bend or fault-propagation folds, and therefore the component of shortening accommodated by this folding would be blind. Associated slip on the décollement would not continue to the east, and thrusting found to the east would represent additional stratal shortening.

A sinuous-bed minimum estimate of shortening by folding can be estimated from a determination of the fold wavelength and amplitude (Fig. 6). Given the above fold geometry, a wavelength can be gauged using the map distance between axial traces. A minimum value for amplitude can be gained by observing in air photos whether individual strata are folded within the topographic relief or exceed it. Using the area Fig. 3b was constructed from (where the best control across the greatest width of the zone exists), a value of 250-300 $\mathrm{m}$ results for the amplitude on the upper Kapp Starostin Fm. boundary with a corresponding average wavelength of $800 \mathrm{~m}$. A chevron fold geometry provides a minimum shortening since it is a straight line distance from crest to trough (Fig. 6). A perfectly concentric fold geometry provides an upper limit. With the above values and assumptions, shortening estimates range from 14 to $25 \%$ (of original length) for the folding. Considering the fold form, $20 \%$ (some $2.2 \mathrm{~km}$ across the width of the zone) is taken as a likely average between the two extremes presented. A conservative sinuous-bed estimate from Fig. $3 b$ yields a similar result. Such an estimate is a minimum since small scale thrusts that were observed in one case (Fig. 5b) and are likely more numerous, are not included.

Using the above approach and assumptions, 
a range of possible depths to décollement, as measured from the top of the Kapp Starostin Fm. within synclinal hinges, can also be calculated (Fig. 6). Considering the $400 \mathrm{~m}$ stratigraphic thickness of the Kapp Starostin Fm., the computed range of $364-694 \mathrm{~m}$ is consistent with a placement of the basal décollement within the base of the Kapp Starostin Fm. or more likely within the underlying Gipshuken Fm.

From experience elsewhere in Spitsbergen's Tertiary structures, higher detachments within exposed Triassic strata can be expected (Maher et al. 1986; Haremo \& Andresen 1988; Dallmann 1988). Some folds within Triassic strata of the study area have wavelengths of several hundred meters or less, and may indicate the presence of such higher detachments.

The map expression of the central zone, dominated by folding, thins and disappears to the north, and near the end of Kongsfjorden the two adjacent zones appear to merge (Fig. 2). An anomalous zone of structures occurs near to where the central zone may disappear, and this coincidence and possible explanations are discussed further below.

\section{Eastern zone of thrusting and stratigraphic ascent of slip}

Two major thrusts that are interpreted to emplace Permian Fm. strata over Triassic strata are exposed in the southern part of the study area. In both cases the thrusts and associated predominantly fault-bend folds are assumed to be the result of climb of the basal décollement from a flat within the Gipshuken Fm., up through the Kapp Starostin Fm. on a ramp, into Triassic and younger strata, in which they probably formed another series of ramps and flats. However, the structures that accommodated the slip at a higher

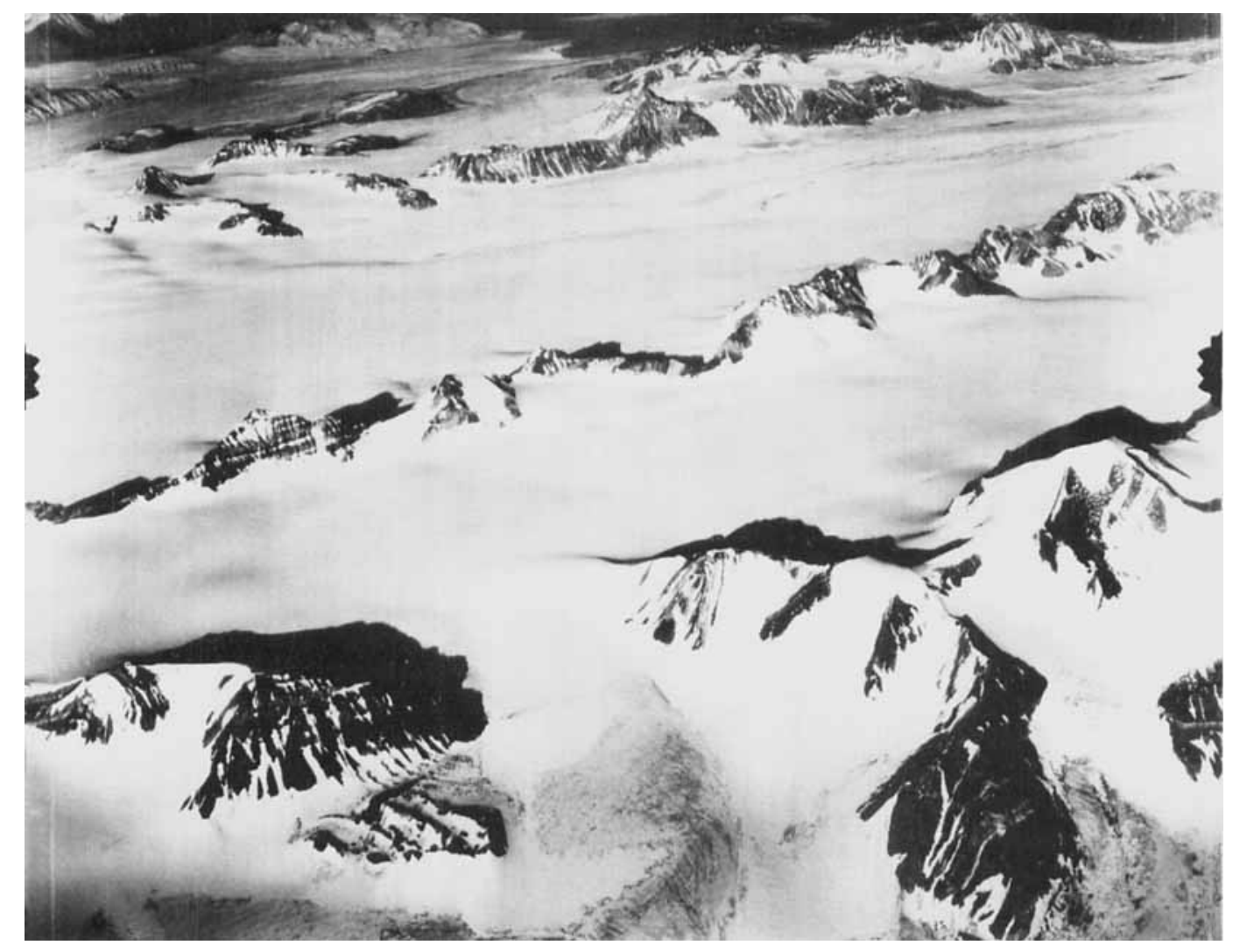

Fig. 5a. Oblique air photo of tight folds in Kapp Starostin Fm. strata of Kvelpane in the foreground (see also Fig. 3b). View is to the east with Ekmanfjorden in the background. 


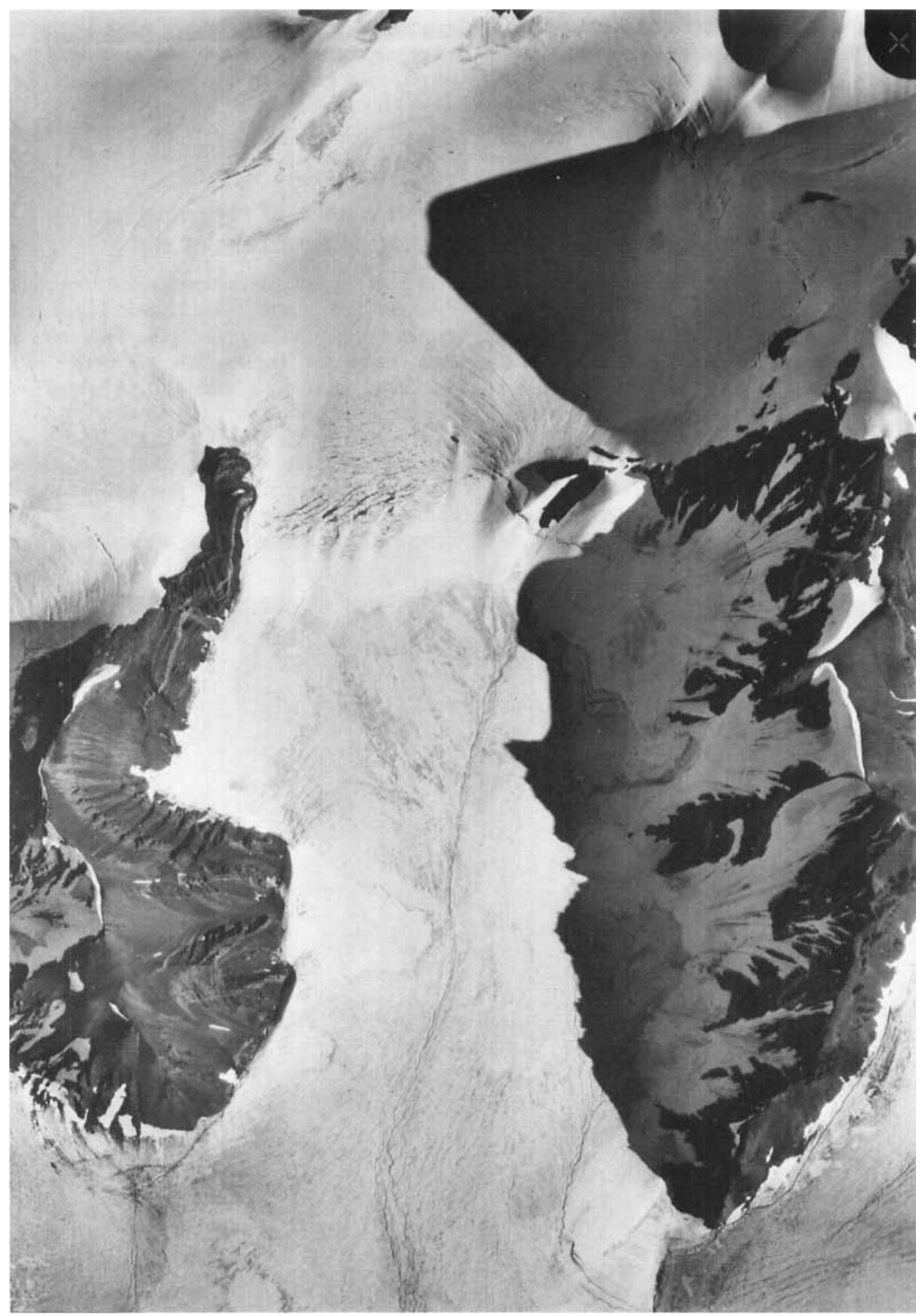

Fig. 5b. Vertical stereo pair of folds in Kapp Starostin and Triassic strata of Devikfjellet. Note small thrust in Kapp Starostin strata. North is to left. The photo edge is about $3.4 \mathrm{~km}$ long. 


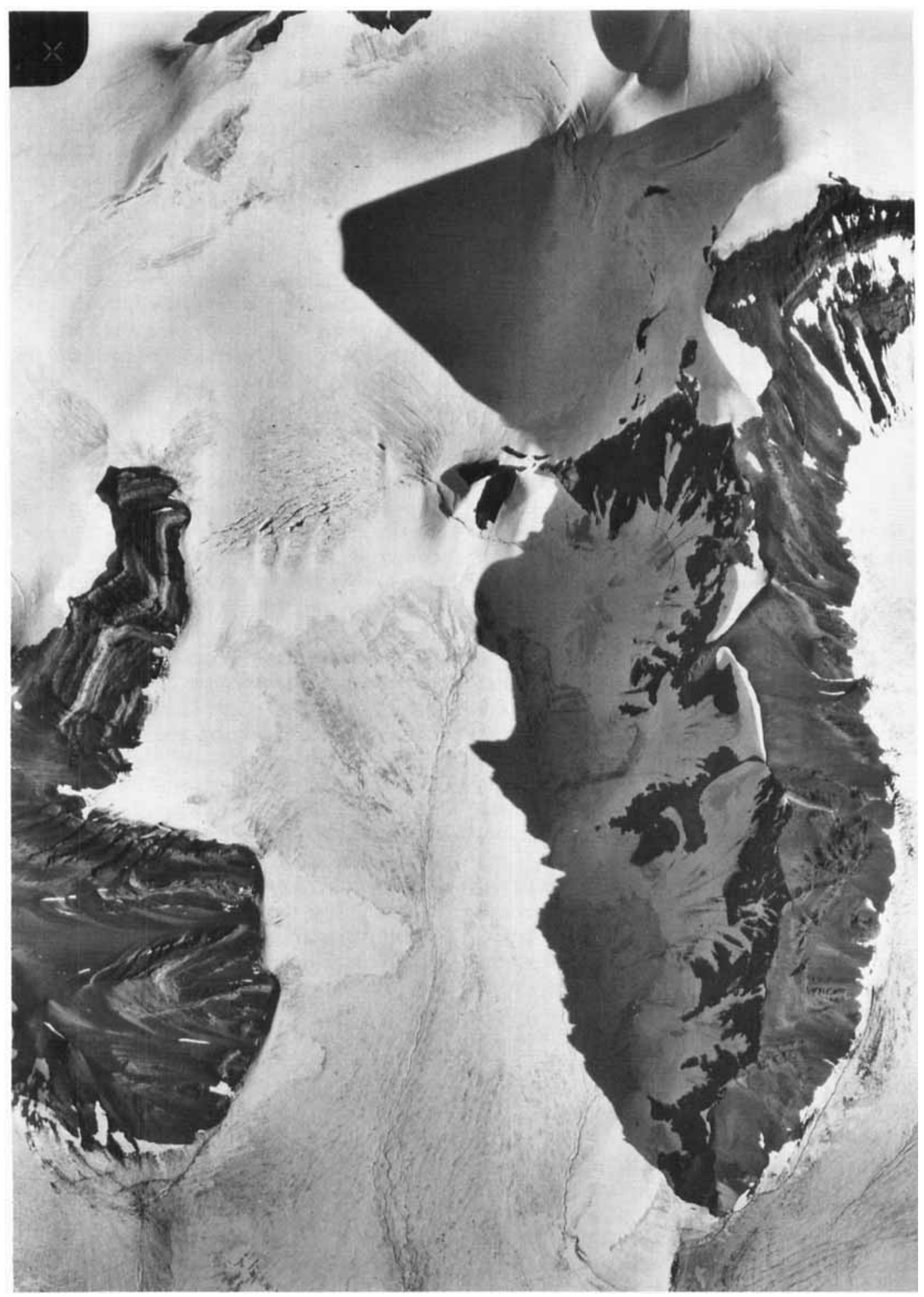




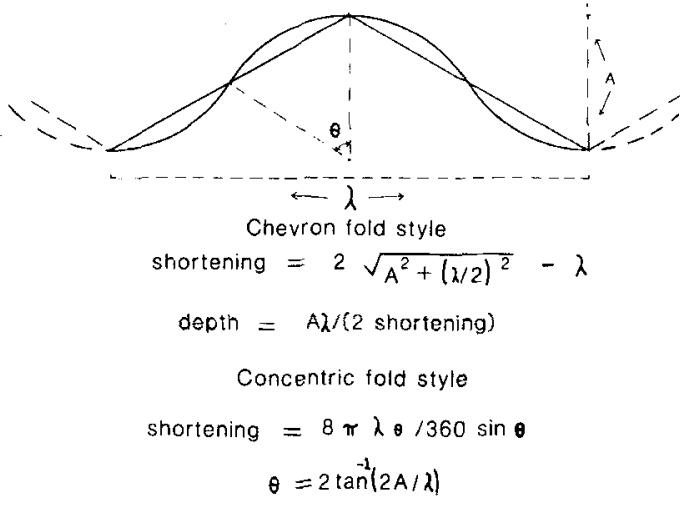

Fig. 6. Idealized fold geometries allowing estimates of shortening based on fold wavelength and amplitude.

stratigraphic level are not exposed north of Isfjorden.

The westernmost thrust recognized on air photos occurs in the ridges and nunataks between Sveabreen and Wahlenbergbreen (Fig. 3c). Air photo interpretation (Fig. 2) suggests that along strike from southeast to northwest the following is exposed (thrust terminology from Boyer \& Elliot 1983; Woodward \& Boyer 1985): a) a hangingwall flat or low-angle hangingwall cutoff of Kapp Starostin Fm. strata above a hangingwall flat or low-angle ramp footwall cutoff of upper Kapp Starostin Fm. to basal Triassic strata; b) a ramp antiform with hangingwall cutoff of Kapp Starostin Fm. strata above a low-angle, footwall ramp of Triassic strata; c) a Kapp Starostin Fm. hangingwall flat overlying a footwall cutoff and syncline of Kapp Starostin Fm. and Triassic strata. These may represent an intermediate, higher and lower view, respectively, of the same thrust. Given the topographic relief of some $500 \mathrm{~m}$ over which the thrust is preserved at the south end of Mediumfjellet, the moderate dip of the thrust, and the above interpretation, $1 \mathrm{~km}$ of movement on this thrust represents a minimum, and $1.4 \mathrm{~km}$ is likely. Local complexities, while difficult to resolve, suggest at least two other thrusts are present just to the east.

The easternmost recognized thrust of this zone is exposed west of Lappdalen on Umefjellet (Flood et al. 1971; Bergh et al. 1988b). Here Kapp Starostin Fm., and locally, Gipshuken Fm. strata structurally overlie Triassic clastics (Fig. $3 c)$. An overlying complex ramp antiform, with a hangingwall cutoff, seems to exist along part of the thrust. On a ridge just west and northwest of
Umefjellet a well developed monoclinal flexure facing west is also readily apparent on air photos. If this represents the trailing edge of a large, but complex ramp antiform (which may die out to the south), then a subsurface ramp where Kapp Starostin Fm. strata are being truncated could be inferred. Such an interpretation implies a minimum movement of $3.0 \mathrm{~km}$ on this fault. Another thrust within the Kapp Starostin Fm. on the southern face of Umefjellet is also evident in the air photos. However, the amount of movement on this fault could not be resolved in this study. Field mapping of some of these structures has been completed (Bergh et al. 1988a,b), and will be continued by Andresen and students (pers. comm.).

While the Lappdalen thrust may be regarded as the foreland edge, with undeformed strata farther east, it clearly represents the edge as presently preserved in this area by the erosional level. The minimum of $3.0 \mathrm{~km}$ of slip would have been accommodated farther east at higher stratigraphic levels likely within the overlying Janusfjellet Subgroup shales that behave so incompetently elsewhere (Dallmann 1988). The observation that the Lappdalen thrust is almost on strike with Longyearbyen is in complete accord with recent work by Andresen et al. (1988), Bergh et al. (1988a), and Haremo \& Andresen (1988) on the presence of Tertiary structures along and west of the Billefjorden fault zone south of Isfjorden, and is also in accord with work by Nøttvedt \& Rasmussen (1988) and Bergh et al. (1988a) documenting the presence of Tertiary structures underneath Tertiary strata of Spitsbergen's central basin. The thrust fault evident within the Tertiary strata near Grumantbyen (south shore of Isfjorden, Flood et al. 1971) is one hint of such underlying deformation.

Also, three observations suggest that at least minor slip continues east of Lappdalen within the strata exposed north of Isfjorden. First a fold occurs within Triassic strata on the east side of Lappdalen (the thrust is just west). Some slip on an underlying slip surface is therefore likely. To the east, Triassic and older strata show only shallow dips to the west, but locally within Gipshuken Fm. gypsums on Palatiumfjellet significant deformation is evident in outcrop and to a considerably lesser degree is also evident at Kolosseum at the end of Ekmanfjorden (Keilen pers. comm.). A thrust of unknown magnitude also may exist on Blomesletta (Lauritzen, field map). 


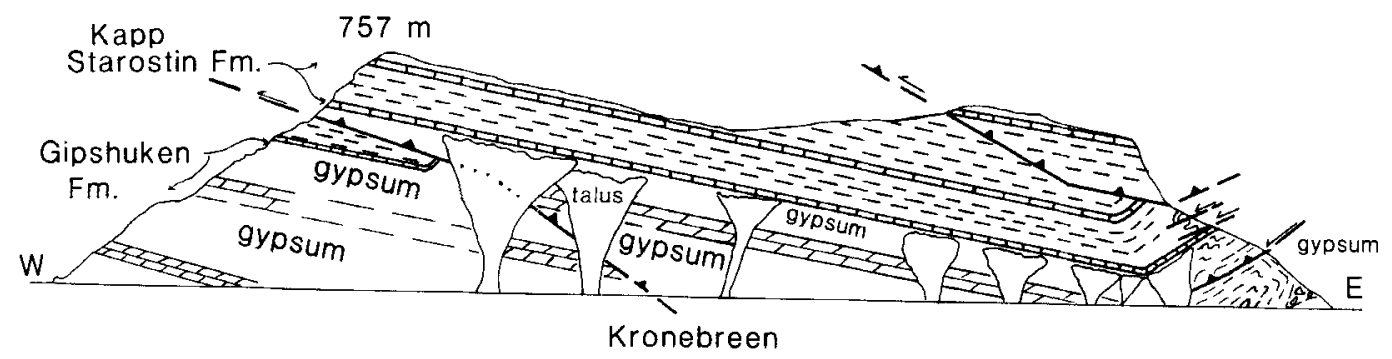

$200 \mathrm{~m}$ MSL

Fig. 7. Photo sketch of Tertiary structures on $\mathrm{N}$ face of Garwoodtoppen. Drawn from slide taken by Hilde Keilen.

Due to Sveabreen and Kongsvegen, this zone of thrusts is not well exposed in the very interior of Oscar II Land, but structures on Garwoodtoppen, near where Kongsvegen and Kronebreen meet in the northern part of the study area (Fig. 2), probably represent the northward continuation of the zone. Photos (from Keilen) were used to draw a photosketch cross-section (Fig. 7). Two thrusts that ascend through Kapp Starostin cherts have a minimum of $500 \mathrm{~m}$ of shortening (taking into account the oblique cut provided by the north face of Garwoodtoppen).

\section{Changes in structural style along strike}

The notable thinning in map view of Tertiary structures within the platform cover strata, from some $25-30 \mathrm{~km}$ in the south to some $5-10 \mathrm{~km}$ in the north of the study area (Fig. 2), and associated changes in structural style can be explained by some combination of four different factors.

An important factor is differential levels of exposure of the thin-skinned deformation, deeper to the north. From Nordenskiöld Land to northern Spitsbergen successively older rocks are exposed from Tertiary strata to Devonian clastics or Hecla Hoek basement rocks. As the erosional surface cut deeper and removed more and more of the upper plate rocks the map width of the deformed platform cover rocks would decrease and the limit of deformation would shift westward of a simple strike continuation. This factor may also explain why the 'staircase' folds of Kapp Starostin Fm. are found only in the southern half of the study area as discussed above. However, such a factor alone would not account for the thinning and disappearance of the central fold zone between the two adjacent zones.

A second and very interesting factor is the differential thickness of platform cover strata along strike and the availability of glide horizons in which flats could form. Tertiary strata south of Isfjorden lie unconformably on Cretaceous strata, whereas in the Brøggerhalvøya area Tertiary strata lie on top of lower Triassic or even Permian strata. Tilting and related erosion during Late Cretaceous and/or early Tertiary occurred prior to deposition of Tertiary clastics. Because of this pre-deformation pattern, thrusts emerging from Hecla Hoek rocks in the north must have done so at higher crustal levels. Farther east fewer incompetent horizons along which flats could form were available. In the very northern part of the study area Triassic age and Janusfjellet Subgroup horizons would have been largely absent, whereas they are present and notably deformed in the southern part.

A fundamental trait determining beam strength is thickness. Thinner and hence weaker 'beams' would have existed above potential glide horizons in the north because of a corresponding lesser thickness of overlying platform cover strata. Therefore, the width of a potential flat could be expected to be less in the north than in the south. Assuming that the Gipshuken Fm. is the dominant glide horizon within the study area, variable cover thickness may be the reason for the change in width of the central fold zone. It is quite likely that this factor is a major one throughout the Tertiary fold-and-thrust belt. Extending this argument, one can expect that south of Isfjorden deformation propagated even a greater distance eastward with the addition of more overburden. At the same time, to the south gypsum is more 
sporadically present. Thus, the Gipshuken Fm. is a less favorable glide horizon and horizons within the Triassic strata take their place. When the full extent of Tertiary structures that root into the west coast zone is known and constrained cross sections compiled, this idea can be investigated more fully from a mechanical perspective by determining flat widths and stratigraphic position as a function of likely overburden thickness.

A third factor may be the presence of a higher thrust sheet of Hecla Hoek rocks that covers extensions of the platform cover structures underneath. The Brøggerhalvøya area, where folds in Carboniferous strata can be traced underneath a thrust sheet with Hecla Hoek rocks in the hangingwall, suggests the operation of such a factor.

A final factor is a change in transport direction and/or magnitude along strike. Transport direction in the Brøggerhalvøya area farther north is variable but includes indications of a counterclockwise swing to the north (Challinor 1967; Kellogg 1975; Lepvrier pers. comm.). A slight clockwise bend is evident in the southern part of the study area, along the north shore of Isfjorden. Between the two areas Hecla Hoek outcrop follows a roughly arcuate pattern. One important test of the last two factors will be to trace Tertiary structures from platform cover strata where their age is clear into the Hecla Hoek rocks (Ohta pers. comm.).

\section{Suggestions for further research}

While detailed mapping will be necessary to test the interpretation and analysis presented here, several areas stand out as anomalous and in need of further research. One such area is at Syltoppen just north of Borebukta (Fig. 2), where a fault and folds to the southeast of it have an anomalous northeast trend, oblique to folds with a more typical northwest trend just north of the fault. In that Cretaceous rocks lie on the south side, the north side of the fault has an up component. While this fault could be interpreted as a tear, normal, or wrench fault, the folds with a similar trend suggest it may be a ramp oblique to the northeast directed transport direction. Given the third factor described in the above section, any given flat horizon will be descending along strike to the southeast under an increasingly greater thickness of platform cover strata. Oblique ramps may be a compensatory mechanism allowing a major thrust to climb along strike. Andresen (pers. comm.) indicates that field mapping suggests an oblique ramp may exist along strike to the southwest of the anomalous zone.

A second anomalous zone, also with a northeast strike, occurs near the source of Osbornebreen (whose terminus is in St. Jonsfjorden) just east of Kregnesfjellet $(1002 \mathrm{~m})$. Here Permian and Triassic strata show anomalous east-northeast strikes and are folded (Fig. 2). Immediately across the glacier to the north are Hecla Hoek rocks. On a speculative note this could be another lateral ramp. Slip might be climbing along strike from within Hecla Hoek rocks to initiate a flat within Gipshuken Fm. strata that the central zone of folding formed above.

A third area in which detailed field mapping will likely provide new understanding is at the southeast end of St. Jonsfjorden. This area lies structurally below the 'staircase' folds and may allow determination of the underlying fault geometry, and thereby determination of the contribution of shortening in this zone to the total shortening in the Tertiary orogen.

\section{Conclusions}

1) Inspection of Norsk Polarinstitutt airphotos along with other sources allowed compilation of a structural photointerpretation map of Oscar II Land in which 8 map units (correlated with the known stratigraphy) and numerous specific structures are identified.

2) Analysis of structures indicates extensive thin-skinned tectonics for the area as Harland \& Horsfield (1974) and Bergh et al. (1986b) report, and allows the recognition of three mechanically distinct zones within the deformed platform cover strata. From west to east these are: a) a zone where thrusts involve Hecla Hoek rocks and a distinctive set of 'staircase' folds formed; b) a zone predominantly of folding above an inferred subhorizontal glide horizon in Gipshuken Fm. strata; c) a zone where slip is being transferred by ramps from the Gipshuken Fm. to a level above the Kapp Starostin Fm. strata.

3) Minimum estimates of shortening can be made from the air photo interpretation and suggest that $20 \%$ or more is likely across the width of the zone. While some $4 \mathrm{~km}$ of shortening can be taken as an absolute minimum, $6.6 \mathrm{~km}$ is very 
likely $(2.2 \mathrm{~km}$ from the central fold zone and $4.4 \mathrm{~km}$ from the eastern zone) and the air photo interpretation would permit up to $9.0 \mathrm{~km}$ (an additional 2.4 from the western zone). This compares well with $6-7 \mathrm{~km}$ from the preliminary balancing calculations of Nøttvedt \& Rasmussen (1988), based on seismic reflection data from western Isfjorden.

4) Changes along strike in map pattern may be due to erosion patterns, changing thickness of platform cover strata along strike, a higher thrust sheet covering underlying structures, changes in transport direction, or some combination of the above. The present map distribution of Tertiary structures is not necessarily reflective of their original 3-D distribution; e.g. Tertiary structures no longer preserved may have existed to the north of Brøggerhalvøya in the platform cover overlying the presently exposed Hecla Hoek basement.

5) Two zones of anomalous structural trend may represent lateral ramps, and need to be more fully investigated.

Acknowledgements. - A NTNF fellowship has provided support for this study and is gratefully acknowledged. I thank the Norsk Polarinstitutt for providing facilities, access to air photos, material support, and interaction with other researchers necessary for the completion of this project. University of Nebraska at Omaha is thanked for support during this project also. Dr. Ohta was invaluable in providing feedback on ideas and in bringing much information to my attention. Winfried Dallmann read through an early draft and gave valuable criticism that improved the manuscript. However, all errors or misinterpretations are my own.

\section{References}

Andresen, A., Bergh, S., Hansen, H., Klovjan, O., Kristensen, S. E., Lifbjerg, F., Lund, T., Mair, B. F., Midbøe, P. \& Nøttvedt, A. 1988a: Geometry and structural development of the Biilefjorden and Lomfjorden fault zones in the IsfjordenSabine land area, Spitsbergen. Abstract 18, Nordiske Geologiske Vintermøde, Copenhagen, Jan. 1988, 33-34.

Andresen, A., Haremo, P. \& Bergh, S. G. 1988b: The southern termination of the Lomfjorden fault zone; evidence for Tertiary compression on East-Spitsbergen. Norsk Polarinstitutt Rapportserie 46, 75-78.

Berg, R. R. 1962: Mountain flank thrusting in the Rocky Mountain foreland, Wyoming and Colorado. American Association of Petroleum Geologists Bulletin 46, 2019-2032.

Bergh, S. G., Andresen, A., Midbøe, P., Bergvik, A., Hansen, A. I. \& Ringset, N. 1988a: Tertiær tektonikk på Svalbard; illustrert ved en $ø$ st-vest profil nord for Isfjorden, VestSpitsbergen. Abstract. 18, Nordiske Geologiske Vinterm $\phi d e$, Copenhagen, Jan. 1988, 46.
Bergh, S. G., Andresen, A., Bergvik, A. \& Hansen, A. I. 1988b: Tertiary thin-skinned compressional deformation on Oscar II Land, West Spitsbergen. Norsk Polarinstitutt Rapportserie 46, 51-54.

Birkenmajer, K. 1964: Devonian, Carboniferous, and Permian formations of Hornsund, Vestspitsbergen. Studia Geologica Polonica 22, 193-213.

Birkenmajer, K. 1977: Triassic sedimentary formations of the Hornsund area, Spitsbergen. Studia Geologica Polonica 51, $1-74$.

Boyer, S. E. \& Elliott, D. 1983: Thrust systems. American Association of Petroleum Geologists Bulletin 66, 1196-1230.

Challinor, A. 1967: The structure of Brøggerhalvøya. Spitsbergen. Geological Magazine 104, 322-336.

Dallmann, W. K. 1988: The structure of the Berzeliustinden area: Evidence for thrust wedge tectonics in the Tertiary foldand-thrust belt of Spitsbergen. Polar Research 6, 143-156.

Eldholm, O., Faleide, J. 1. \& Myhre, A. 1987: Continent-ocean transition at the western Barents Sea/Svalbard continental margin. Geology 15, 1118-1122.

Flood, B.. Nagy. J. \& Winsnes, T. S. 1971: Geological map Svalbard 1:500,000. Sheet 1G, Spitsbergen, southern part. Norsk Polarinstitutt Skrifter 154A.

Gjelberg, J. G. \& Steel, R. J. 1981: An outline of Lower-middle Carboniferous sedimentation on Svalbard: Effects of tectonic, climatic and sea level changes in rift basin sequences. $\mathrm{Pp}$. 543-562 in Kerr, J. W. \& Ferguson, A. J. (eds.): Geology of North Atlantic Borderlands. Canadian Society of Petroleum Geologists Memoir 7.

Haremo, P. \& Andresen, A. 1988: Tertiary movements along the Billefjorden fault zone and its relation to the Vest-Spitsbergen orogenic belt. Norsk Polarinstitutt Rapportserie 46 , 71-74.

Harland. W. B. 1969: Contribution of Spitsbergen to understanding of tectonic evolution of North Atlantic region. Pp. 817-851 in Kay, M. (ed.): North Atlantic - Geology and continental drift. American Association of Petroleum Geologists Memoir 12.

Harland, W. B. \& Horsfield, W. T. 1974: West Spitsbergen orogen. Pp. 747-755 in Spencer, A. M. (ed.): MesozoicCenozoic Orogenic Belts - Data For Orogenic Studies. Special Publication of Geological Society of London 4.

Hjelle, A. \& Lauritzen, $\emptyset .1982$ : Geological map Svalbard 1:500,000. Sheet 3G, Spitsbergen, northern part. Norsk Polarinstitutt Skrifter $154 C$.

Holtedahl, O. 1913: Zur Kenntis der Karbonablagerungen des westlichen Spitzb.rgen. II. Allgemeine stratigraphische und tektonische beobachtungen. Jacob Dybwad, Kristiana (Oslo). $91 \mathrm{pp}$.

Kellogg, H. E. 1975: Tertiary stratigraphy and tectonism in Svalbard and continental drift. American Association of Petroleum Geologists Bulletin 59, 465-485.

Lowell, J. D. 1972: Spitsbergen Tertiary orogenic belt and the Spitsbergen fracture zone. Geological Society of America Bulletin 83, 3091-3102.

Maher, H. D., Jr., Craddock, C. C. \& Maher, K. 1986: Kinematics of Tertiary structures in Upper Paleozoic and Mesozoic strata on Midterhuken, west Spitsbergen. Geological Society of America Bulletin 97, 1411-1421.

Maher, H. D., Jr. \& Craddock, C. C. 1983: Transpression as a kinematic regime: West Spitsbergen Tertiary fold-and-thrust belt. Geological Society of America Abstracts 15 (6), 633.

Maher, H. D., Jr. \& Craddock, C. C. 1988: Decoupling as an alternate model for transpression during the initial opening of the Norwegian-Greenland Sea. Polar Research 6, 137-140. 
Myhre, A. M., Eldholm, O. \& Sundvor, E. 1982: The margin between Senja and Spitsbergen fracture zones: Implications from plate tectonics. Tectonophysics $89,33-50$.

Nøttvedt, A. \& Rasmussen, E. 1988: Tertiary deformation in central-west Spitsbergen, as interpreted from marine reflection seismic data. Abstract 18, Nordiske Geologiske Vintermøde, Copenhagen, Jan. 1988, 320-321.

Orvin, A. K. 1934: Geology of the Kings Bay region, Spitsbergen. Skrifter om Svalbard og Ishavet $78,98 \mathrm{pp}$.
Steel, R. J. \& Worsley, D. 1984: Svalbard's post-Caledonian strata - an atlas of sedimentary patterns and paleogeographic evolution. Pp. 109-135 in Spencer, A. M. (ed.): Petroleum Geology of the northern European margin. Graham \& Trotman, London.

Suppe, J. 1985: Principles of Structural Geology. Prentice-Hall, Inc. $537 \mathrm{pp}$.

Woodward, N. B. \& Boyer, S. E. 1985: An outline of balanced cross-sections. University of Tennessee Studies in Geology 11. $123 \mathrm{pp}$. 